region encoding a protein with homology to a conserved DNAbinding motif. Nature, 346: 240-244.

3. Berta, P., Hawkins, J.R. Sinclair, A.H. Taylor, A., Griffiths, B.L. Goodfellow, P.N. and Fellous, M. (1990) Genetic evidence equating $S R Y$ and the testis determining factor. Narure, 348: $448-450$.

4. Jager, R.J., Anvret, M., Hall, K. and Scherer, G. (1990) A human XY female with a frame shift mutation in the candidate testisdetermining gene SRY. Nature, 348: 452-453.

5. Hawkins, JR Taylor A Goodfellow P. N Migcon, C.J., Smith K.D. and Berkovitz, G.D. (1992) Evidence for increased prevalence of $S R Y$ mutations in $\mathrm{XY}$ females with complete rather than partial gonadal dysgenesis. (1992) Am. J. Hum. Genet. 51: $979-984$

6. Koopman, P Gubbay, J Vivian N Goodfellow, P. and LovellBadge, R. (1991) Male development of chromosomally female mice transgenic for Sry. Nature, 351: 117-121.

7. Harley, V.R., Jackson, D.I., Hextall, P.J., Hawkins, J.R., Berkovitz, G.D., Sockanathan, S., Lovell-Badge, R. and Goodfellow, P.N. (1992) DNA binding activity of recombinant $S R Y$ derived from normal males and XY females. Science, 255: 453-457.

8. Ferrari, S., Harley, V., Pontiggia, A., Goodfellow, P., Lovell-Badge, R. and Bianchi, M.E. (1992) A sharp angle in DNA is the major determinant in DNA recognition by $S R Y$ protein, as it is for HMG I protein. EMBO J., 11: 4497-4506.

\section{Early Development}

\section{5}

DIFFUSIBLE FACTORS AND CELL DIFFERENTIATION.

J.B. Gurdon, Wellcome CRC Institute of Cancer and Devel. Biol., Tennis Court Road, Cambridge CB2 1QR, England.

All adult organs consist of several different cell-types; these first appear in embryos, and are then maintained, and usually replenished from stem cells, in later life. In humans and in vertebrate animals, interactions between cells are of overwhelming importance in initiating (and maintaining) cell differentiation. Major advances have recently been made in identifying the kinds of molecules which can initiate cell differentiation in embryos through cell interactions. These include a number of known "growth factors" such as basic FGF, TGF $\beta$, Activin, Wnt- 8 , etc.

These factors, which are products of genes active in early development, are usually short-lived and, in contrast to hormones, are effective only over short distances of a few hundred microns or less than 10 cell diameters. Special mechanisms regulate the distance, and hence numbers of cells, over which these factors exert an influence in early development. One of these is the limited time over which cells are competent to respond to signalling molecules. Another is the nature of the extracellular material by which cells adhere to each other.

The complete specialization of a cell-type usually depends on a sequence of cell interactions, such that cells formed as a result of one interaction, themselves emit a signal to which other cells respond.

Most of the known cell interactions are of the paracrine type involving an interaction between different kinds of cells. But an example is also known in which cells of like type interact with each other, by a "community effect", and apparently by an autocrine mechanism. The general principle by which cell differences are generated in early vertebrate development differs from a typical hormone action in two major respects. First the signals are strictly limited in the distance they travel from their source. Second, many more cells have the ability to respond to the signal (by possession of appropriate receptors) than actually respond in normal life.

Most of the locally acting diffusible factors of the kind just referred to have dramatically divergent effects on different cell-types at different stages of development. This diversity of response to the same factor may be achieved at the level of second messenger pathways or by the selective interaction of proteins with the promoters of early response genes. Examples of this last kind will be described.

Short-lived locally acting factors seem to be of widespread importance in adult stem cells as well as in embryos, and may therefore be of clinical importance in regulating the production of differentiated cells from stem cells, and in preventing the proliferation and spread of cancer cells.

\section{Andrea Prader Lecture}

6

The Andrea Prader lecturer and awardee, selected by the European Society for Paediatric Endocrinology, will be announced at the meeting. 